\title{
Meaningless Acts: Migratory Aesthetics in Krzysztof Warlikowski's and Paweł Miśkiewicz's Dystopian Adaptations of The Tempest
}

\author{
Anna Kowalcze-Pawlik
}

\begin{abstract}
This essay discusses two post-1989 adaptations of Shakespeare's The Tempest in the Polish theatre that use text distortion, fragmentation, and intertextuality as ways of addressing the difficult heritage of World War II. Applying the notion of migratory aesthetics in a theatrical context mobilises the interpretive potential of contemporary theatre as an act of recalling a traumatic past. Generational trauma is addressed and processed through the productions of Krzysztof Warlikowski's Burza (2003) and Paweł Miśkiewicz's more recent Burza Williama Szekpira (2018). These two productions are analysed according to strategies typical of traumatic recall, i.e., dissociation and repression, to reflect on the dystopian elements in The Tempest, aspects already addressed by Jan Kott in his pre-1989 interpretations of the play.
\end{abstract}

\section{Key words}

Shakespeare and the Holocaust, Shakespeare and World War II, memory studies, contemporary Polish theatre, Krzysztof Warlikowski, Paweł Miśkiewicz 
Reenactments of traumatic experience take the form of drama, not narrative, and are thereby dependent on the time frame of the 'parts' scripted in the drama. All the manipulations performed by a director-narrator, who can expand and reduce, summarize, highlight, underscore, or minimize elements of the story at will, are inaccessible to the 'actor' who is bound to enact a drama that, although at some point in the past it happened to her, is not hers to master. (BAL 1999: ix)

'Canst thou remember / A time before we came unto this cell?' (Tempest 1.2.38-39):

\section{Dystopia, Trauma, and The Tempest}

In his 1991 study of modern drama The Plot of the Future: Utopia and Dystopia in Modern Drama, Dragan Klaić discusses the complex influence of modernity on theatre, suggesting that disenchantment with utopia can be seen as a defining feature of the Central European imagination, which, wounded by the past, is not able to trust in the hope of renewal and transformation offered by political projects (KLAIĆ 1991). Instead, Klaić claims, modern theatre focuses on dystopian visions of the present and the future. Dystopia, after all is a type of scenario, or 'a form of resistance in and for our times' (BACCOLINI 2013: 44) in which we strive to 'exorcise one's ghosts' (GALLARDO 2013: 39). Such a critical and mistrustful, and yet obsessive concern with the difficult heritage of the past became apparent in the Polish post-1989 theatre, with a new generation of directors willing to address troubling questions about matters of history. ${ }^{1}$ The predominant context which frames the emergence and discussion of dystopian theatrical practices in Central and Eastern Europe includes, first and foremost, the trauma of World War II and the horror of the Shoah; the mass movement of people during the wars; the massive displacement of large populations owing to the shifting boundaries in the aftermath of the war; the trauma of the 1968 state-organised displacement of the remaining Jewish population in Poland; the state of flux in which the Central European population found itself once the Iron Curtain was lifted and mobility became an option available to large portions of the society. These still largely unprocessed experiences bear upon the lives of the second- and third-generation of World War II trauma victims (HIRSCH 2012), who became also affected by more recent contexts such as the unbounded mobility within the utopian project of the European Union, as well as new migration politics resulting out of the political inclusions and exclusions accompanying EU membership.

In a reflection on the aesthetic changes tied to the emergence of new forms of expression, one can make use of migratory aesthetics, a theoretical amalgam which functions predominantly in the sphere of the visual arts but can also be used to analyse the performative arts. These aesthetics question unitary identity politics, i.e., the internal cohesion of languages and peoples, pointing instead to the causes and effects

1 For a detailed discussion of the history of the Polish theatre before and after 1989 see (ŚMIECHOWICZ 2018). 
of linguistic, economic, and political marginalisation and the ways people become excluded. The larger aim of a migratory work of art is to engage the audience to think and respond affectively to the lived experiences of others, who are often put in the position of the Other by political regimes and violent populist movements. Mieke Bal argues that as a theoretical notion, migratory aesthetics does not necessarily entail the experience of migration as such, or the figure of the migrant (BAL 2007: 23), but instead is tied with the loss of distinctions and a realisation that 'centre is nowhere;' this analytical tool points to the displacement and an opposition to the colonial impact of Eurocentrism as a defining aspect of migratory cultural practices (BAL 2007: 34). As such, it highlights trends characteristic of the new performative tradition emerging in Poland since the 1990s, one which has been largely informed by contacts with the German stage, shaped by the introduction to the theory and practice of postdramatic theatre, and is responsive to the generational need to speak with the ghosts of the past. When one speaks of trauma as silenced, narrativised or alluded to on the stage, it is useful to consider both the subject matter of the play and the form of the production, which ideally work as a conduit for the thought and the accompanying affect in the director, designers, actors, and the audience. In one of her early discussions of the affective potential of art Bal notes:

Art [...] can mediate between the parties to [a] traumatizing scene and between these and the reader or viewers. The recipients of the account perform an act of memory that is potentially healing, as it calls for political and cultural solidarity in recognizing the traumatized party's predicament. (BAL 1999: x)

Theatre as a vehicle of engagement with the lived or staged experience of trauma can be looked at as a medium in which migratory aesthetics may be put to affective work, as theatre can provide a framework for addressing the 'wounded past' to create an emotive reaction in the audience. The affective potential of Shakespearean plots can serve as a potent tool in this respect, and the utility of these works has been duly noted in a number of educational and art-therapy-related studies on the subject (e.g., JONES 1996; LANDY 2011; LANDY and MONTGOMERY 2012; HEARD et al. 2013). The exclusions befalling Shakespeare's characters may be used in theatre to speak of the traumatic experiences of the collective past that will resonate with the audience, possibly activating its emotional response. It is between the stage and the audience that the act of the affective remembering of the past occurs, so that the viewers might become 'the recipients of the account' of the trauma present in such adaptations in the form of a cipher, a code message, and/or an intertextual allusion. It is such acts of engaging the often indirect, repressed, or displaced memory that are the subject of this writing. ${ }^{2}$

This essay discusses the emergence of the dystopian post-memory of the traumatic $20^{\text {th }}$ century in the dramatic productions by two eminent theatrical directors active on the Polish scene after the 2000 publication of the work Neighbours: The Destruction

2 For a discussion of postmemory in Polish theatre see (BRYŚ 2020). On trauma in contemporary performance see (DUGGAN 2018), on trauma and Shakespeare, (SILVERSTONE 2012). 
of the Jewish Community in Jedwabne, Poland by Princeton University historian, Jan Tomasz Gross. This book critically examined the July 1941 massacre of the Jewish population by their Polish neighbours in Jedwabne in northeast Poland. Gross' history, published in English in 2001, has been regarded as the point which marked the onset of the preoccupation of the new post-war generation with the guilt of the forefathers. The work gave rise to pertinent questions about the Polish past and the difficult heritage of the war and the Communist era (NIZIOŁEK 2013: 501-503). The theatrical productions analysed here are two adaptations of Shakespeare's The Tempest, a play which despite its comic potential and relatively brief staging history in this region, has had a complicated reception history in Central Europe, with Poland as a particularly striking case in point. ${ }^{3}$ Staged for the first time in 1901, until the end of World War II it remained safely cached within the comedic interpretive tradition. As Anna Cetera writes in her introduction to the most recent translation of The Tempest by Piotr Kamiński:

The Tempest certainly was fit to serve as a singing and dancing [wedding reception] interlude [...]. But on a deeper level this very same drama haunts one with the open festering wounds that were only provisionally dressed with Miranda's wedding veil at the close of the play (CETERA 2012: 12). ${ }^{4}$

The year 1989 was a symbolic caesura that allowed the new generation of directors to rip that provisional bandage off, if not exposing the wounds of the past to the healing airs of open discussion and dialogue, then at least making them felt by the theatregoing public.

'In the dark backward and abysm of time' (Tempest 1.2.50):

\section{The Tempest before and after 1989}

In his 1987 preface to the second Polish edition of Shakespeare, Our Contemporary, Jan Kott mentions his correspondence with the Hungarian philosopher and literary historian György Lukács, who was one of the first readers of the German translation of Kott's study of Shakespeare. Lukács criticised Kott's approach to Shakespeare, writing that the Polish scholar underestimated the importance of Renaissance hope present in Shakespeare's drama. He claimed that through the Great Mechanism of history Kott 'generalised the historical experience of Stalinism' (Lukács quoted in KOTT 1990: 11). In the Preface, Kott refers to Lukács's polemics, in one sentence laying out the sum of

3 For a brief discussion of The Tempest's stage history in Poland, see (SAKOWSKA 2011); for a discussion of The Tempest in Central Europe, see Pavel Drábek (2013: 26), who reflects on the 'turbulent and tempestuous' cultural history of the reception of the play in Czechoslovakia/the Czech Republic; for the reception history of The Tempest in Slovakia see Jana Bžochová-Wild's monograph (2003). For a discussion of the early history of The Tempest on the Polish stage, see (POŻAR 2020).

4 All translations are my own unless otherwise stated. 
the Polish historical experience and the significance of his own highly contextualised reading for the reception of Shakespeare in Poland:

In a country, where all the months of the year, from January to December, from February to November, are the months of the memory of 'blood and honour,' but never of 'salvation,' this Shakespeare, my Shakespeare, cruel in his tragedies and bitter even in his comedies, will not cease to be contemporary for a long time. (KOTT 1990: 11)

Kott's sense of the notorious Polish historical predicament is here fashioned into a source of austere knowledge: his localised reading of Shakespeare is pitted against the possibility of a hopeful interpretation.

Even though Kott refused The Tempest the same presentist potential with which he credited Hamlet, the disenchanted reading of the play by him and other Polish critics active in Communist Poland suggests a striking change in the interpretive scripts surrounding The Tempest in Poland after World War II. It also points to the socio-historical factors that played a role in local, Central European re-interpretations of Shakespeare as a political thinker/writer. This changed context seems to have paved the way towards theatrical adaptations that would utilise the politically dystopian, and would modify or dismiss the 'naively' aesthetic utopian tradition of The Tempest in performance. In the years following the fall of Communism in Poland, the play was among those dramas by Shakespeare that found their way into the repertoire more than occasionally both in public theatres and in television theatre, which in Communist Poland had served a didactic and aesthetic function for those viewers who did not have immediate access to stages in their area. ${ }^{5}$ In 1991, Laco Adamik directed a televised theatre production which was remarkable not only because it heralded the comeback of television theatre on Polish TV after 1989, but also for the use of the first digitalised setting filled with red rocks, a suitable background for the cast, who were all dressed in red with the exception of Zbigniew Zapasiewicz, who as Prospero was clad in black and gold. This colour symbolism is interpreted by Jacek Fabiszak and Natalia Brzozowska as possibly bearing some political undertones (FABISZAK and BRZOZOWSKA 2011: 360-361), with Prospero opposing cynical and corrupt politicians. The 1990 Krakow Slowacki Theatre adaptation of The Tempest by Jerzy Goliński, who had already directed an avant-garde production of the play in Opole in 1978, was not met with critical acclaim, but rather with exasperated confusion. Interestingly, Goliński chose The Tempest to initiate his artistic directorship in the theatre, whose situation was exceptionally difficult owing to the very poor conditions of both the stage and the ensemble, the former in the midst of a renovation and the latter in a crisis created by previous directors (SIENKIEWICZ 1990). The choice of the play itself, surprising for some reviewers, suggested to others an awareness of larger trends within

5 Laco Adamik's biography is a living testament to the migratory experience of many artists in Central Europe. Born in Slovakia, Adamik followed his wife Agnieszka Holland to her mother country when the political situation in Czechoslovakia deteriorated in the 1970s. Holland herself faced ostracism owing to her Jewish heritage, but Adamik adapted to his new cultural reality and became a television theatre director. 
the European theatre at the time (CZAPLIŃSKI 1990). ${ }^{6}$ The setting of the production, which ran for six months, reflected the forced state of frenzied anticipation typical of the Polish society at the time: the stage itself was rather symbolically, but also pragmatically, separated from the auditorium by an iron curtain, behind which construction continued nonstop. The violently comical scene of the anal rape of Caliban [sic $]^{7}$ contrasted with the haunting beauty of Miranda's and Ferdinand's foray into a landscape filled with huge chess pieces as if the characters were but tiny players stranded in a game they could not win (KUBIKOWSKI 1991). The royal entourage dressed all in red, wearing neck-ties and tossing a crown among themselves, were read along rather obvious political lines, as the first free presidential elections were being organised around the same time. ${ }^{8}$ The 1990 production was discussed as a 'rough and crippled Tempest amidst ruins', 'teeming with actor aggression, a testimony to the confusion of despair and hope' (NYCZEK 1992) of a disenchanted Prospero (Jerzy Goliński) and a blood-thirsty Caliban (Krzysztof Jędrysek in a very proletarian, working-class-like portrayal), with a mundane Ariel in overalls. Tadeusz Nyczek compares this 1990 adaptation with another attempt at restaging the same production by Goliński in 1992:

The first Tempest was staged in the Słowacki Theatre during its renovation, and it made people aware of the situation of the theatre troupe - a group of true castaways. [...] Since then, the ruins have again turned into the National Shrine of Art. They shine like new and do not resemble the ship from the beginning of the play, but from its finale, miraculously saved and in a reasonable shape. (NYCZEK 1992)

The 1992 production was elegant, nuanced, and offered a much more enjoyable spectacle: 'a fairy tale about a theatre saved; and about a path to salvation through experience' (NYCZEK 1992). The 1990 and 1992 Krakow Słowacki Theatre Tempest can serve as a synecdoche for the precarious situation of the 1990s Polish theatre, 'rough and crippled amidst ruins' but caught up in the capitalist illusion of endless possibility; still dreaming the dream of future freedom in which one can temporarily forget about the past while neglecting the present. The exasperated wait for political change and the largely unfulfilled promise of a free and independent country that nearly went bankrupt in the process translated into a more general state of stasis within the theatrical world. As Dobrochna Ratajczakowa remarks in her discussion of the situation of the Polish theatre during the transformation:

6 Lesław Czapliński (1990) notes: 'The new artistic directorship [...] chose as its inauguration Shakespeare's The Tempest, recently back in fashion in the theatrical world; Peter Brook has just staged it in Paris.'

7 This particular scene is attributed by Elżbieta Konieczna (1990) to the influence of a lecture by Jan Kott: 'Many people present at the theatre remembered the inaugural lecture by Professor Jan Kott at the Krakow National Academy of Theatre (PWST) about the homosexual, bisexual, and other unnatural sexual attractions of the characters of Shakespeare's plays. The dean of the directing department, Jerzy Guliński [...] put Professor Kott's hypotheses into action on the stage.' (KONIECZNA 1990)

8 The elections were a clear context for some reviewers: 'They will repeat the criminal gestures without scruple - they are, after all, officers - professionals; they create a shadow cabinet that is ready to make real crimes happen' (RUDA 1990). 
From an artistic point of view, the period 1989-2004 lacked excitement, while the dominant mood of helplessness sanctioned only isolated events. [...] In the Polish Romantic tradition, unhappiness is understood to be a measure of human greatness. Polish theatre of the period [...] did not respond nearly enough to the social transformation, just as the society itself would not face up to it. (RATAJCZAKOWA 2007: 23-26)

The fall of Communism brought about a number of important changes in the theatrical world. The transformation was a difficult time not only politically, but also economically, with the cultural sector feeling the recession most acutely. Although there were no major theatre closures and the majority of theatres were spared in the process of painful economic transformation, the companies were affected by the introduction of capitalist practices into the sphere of culture production and management. The difficult but hopeful time of the transformation resulted in the pauperisation of theatrical institutions, the emergence of the entertainment theatre, and the commercialisation of the repertoire: trends which many directors educated in the 1990s fervently opposed.

\section{'I have suffered / With those I saw suffer' (Tempest 1.2.5-6):}

\section{Warlikowski's Theatre of the Excluded'}

One of the earliest post-1989 Shakespearean adaptations to tackle the difficult heritage of the past and create a clear-cut break with the traditions of high-art Shakespeare was Krzysztof Warlikowski's 2003 The Tempest staged in the Warsaw-based Rozmaitości Theatre. ${ }^{10}$ This much discussed production originated as a part of the new initiative of the Rozmaitości Theatre to create alternative offerings for younger audiences. The staging was directed by Krzysztof Warlikowski, a student of the eminent director Krystian Lupa, the enfant terrible of the Polish repertoire theatre, and an émigré, whose theatrical company exists till this day without permanent institutional support. Warlikowski was one of the first Polish theatre-makers to address the issue of memory that falsifies and silences an uncomfortable past, using Shakespeare to this end more than any other Polish director. ${ }^{11}$ His production of The Tempest, which won him the Gdańsk Shakespeare Festival Golden Yorick for 2003, fully activated the dystopian potential of the play as a medium through which historical trauma can be engaged and explored. ${ }^{12}$

9 The expression 'theatre of the excluded' is used by Katarzyna Fazan in her interview with Krzysztof Warlikowski (WARLIKOWSKI 2012).

10 A critical re-evaluation of tradition is something that Warlikowski seems to have started formulating already in the 1990s, when he participated in a directing workshop organised by Peter Brook in Vienna in 1992 (DROBNIK-ROGERS 2009: 12).

11 As Warlikowski himself admits, his work on Shakespeare is influenced by his repeated readings of Kott; but where Kott thinks it is unnecessary to contextualise and render The Tempest contemporary for its audiences, Warlikowski takes the opposite view, locating his adaptation in the regions very close to home.

12 Ratajczakowa describes the performances appearing on that stage as what "paved the way for a new theatre language: utilising mixed media, the aesthetics of "real" events, of peep shows and of performance. They also saw the breaking of taboos through nudity, homosexuality, and transsexuality, often staged in 
In Warlikowski's The Tempest the character of Caliban is played by the Austrian actress Renate Jett, who self-identifies as belonging to the 'generation of the guilty', i.e., the generation of Austrians and Germans born after World War II (JETT 2011). In this production, the power of Prospero is spent already at the beginning: for almost the entire length of the staging Adam Ferency remains seated at an empty table, an image of irresolution and lack of will to live. Caliban, Ariel, and Miranda are all caught in the prison of Prospero's dysfunctional vision of family life and are equally resigned to their fates (FABISZAK and BRZOZOWSKA 2011). Ariel is a spirit caught in the prison of their own gender-fluid body and dies once granted freedom by their unloving master; Caliban speaks only broken Polish, with a German accent lending an eerie, haunting quality to his ragings and complaints: 'this crippled slave-speak was a visible sign that Prospero has failed' (PAWŁOWSKI 2003: 187). The island is presented as 'Arcadian remains', in which the dream of freedom has transformed itself into a nightmarish vision of indecision and despair (PAWŁOWSKI 2003: 187). The magical, world-changing qualities of language are lost not only on Caliban, but all the other characters, most notably on Prospero as the word-smith whose power is broken beyond repair. The speeches are slurred, the actors' articulation forced:

Actors articulate words slowly and often awkwardly. There are long purposeful pauses when the actors appear to let the words sink in. Time drags, making the experience of watching the actors uncomfortable. Prospero speaks dispassionately and the script makes his utterances economic and authoritative, devoid of any niceties. His eyes hardly move and do not make contact with others. (SAKOWSKA 2011: 332)

This dispassionate delivery accompanied by temporal disruptions and lags is identified by Sakowska (2011) as a postdramatic practice, but it is also evocative of the painful, discontinued, and reluctant process of traumatic recall. All the actors play the part of survivors trying to cope with a catastrophe that has already happened and is witnessed by the audience only through a series of fragmented, largely aural reconstructions: echoes of airplane sounds and pilots' commands; Miranda and Prospero's argument in the dark. The plot becomes distorted and goes askew. The belated, distorted, and fragmented representation of the violent crash structurally repeats an almost somaticised reaction to a traumatic memory. As Sakowska notes, the initial scene of wreckage is postponed until act three, scene two, and, significantly, appears instead of the banquet scene:

stark ways with brutal actions. [...] This new language used often unrelated associations, radical conceptual shortcuts, snapshots from films and commercials, and drew on a poetics of dramatic flotsam, and jetsam, and fast montage. Physicality, violence, sex, nudity, brutality, and coarse language shifted it closer to the conventions of reality shows. Such a theatre needed radically modernised classics and presented a drastic picture of the current times which could storm the "cultural indifference" of spectators' (RATAJCZAKOWA 2007: 24-25). Six years later Grzegorz Niziołek (2013) looked back at that same landscape and saw what he described as 'the Polish theatre of the Holocaust' in his monograph by that very title. 
the castaways $[\ldots]$ have to relive the crash of the aircraft in the manner of a terrifyingly grotesque dumb show. The actors playing Alonso, Antonio, and Sebastian, seated in comfortable plane seats, appear to wear strangely distorted masks of their own likenesses. They convulse and shake uncontrollably as the airliner is about to smash into the island. Ariel mimes mockingly the gestures of a stewardess showing emergency exits and how to use oxygen masks. Suddenly it is all over and the lights show the three actors standing by the seats of their body doubles, slumped dead in their chairs. (SAKOWSKA 2011: 330)

The interpretive potential of trauma in Warlikowski's production was lost on the majority of critics at the time; they focused on the familiar trope of the political Shakespeare and criticised Gonzalo's stutter, which was especially audible in the description of his utopia. The topical allusion to the editor-in-chief of the leading Polish journal Gazeta Wyborcza, Adam Michnik, and the then-recent political corruption scandal in which the stuttering journalist was cast in a leading role seemed all too apparent (KISTNER 2007: 357-358). Sakowska observes though that the suffering of The Tempest's characters should be read through 'a Freudian-Lacanian lens' of loss (SAKOWSKA 2011: 333). Indeed, within memory studies 'the "timeless" duration, relentless repetition and narrative splitting-off' are all signals of traumatic recall, an act of traumatic (non)memory in which painful events resurface without becoming integrated into the order of narrative memory (BAL 1999: ix). Sensory disintegration, time distortion, distorted perception, the uncanny appearance of doubles, the intrusion of death, even the presence of mirrors: these are the operations of unwanted memory and symptoms of repressed pain.

Dariusz Kosiński points to the violence of the theatrical event and the violence of the spectator's gaze as characteristic features of much of contemporary Polish theatre, underlining the affinity between Krzysztof Warlikowski and Jerzy Grotowski in this respect: 'As far as situating the audience in the position of a violent gaze, Warlikowski's theatre emerges as a late echo of Jerzy Grotowski’s theatre' (KOSIŃSKI 2014: 361). Grotowski also tackled the trauma of the Shoah in his 1964 production of Hamlet by the 13 Rzędów Theatre in Opole. Significantly for postmemory practices and the migratory aesthetics that they ascribe to, Grzegorz Nizolek (2013) discusses Warlikowski's strategy of situating the audience in the position of the 'bystander'. In an interview given around the time of the premiere, Warlikowski points to the discussions surrounding the question of Polish participation in the extermination of the Jewish population during World War II:

Working on The Tempest, I remembered Jedwabne and the celebrations of the year before. Those who were close to these events, the witnesses, the prosecutors and the historians have already spoken; some were upset, others were obsequious. Now it is about us, what we will do with it. Will we behave differently than our fathers and grandparents? Will we cherish these places; will we learn respect for the victims, respect for the neighbour? Imagine a situation when a boy from this village suddenly falls in love with a Jewish girl from Israel who came to Jedwabne for the remembrance ceremony. That is The Tempest. By a Shakespearean 
miracle, Ferdinand and Miranda fall in love, even though they live on different planets. (WARLIKOWSKI 2003)

The sense of the hopeful expectation Warlikowski speaks about in this passage is, however, nowhere to be found in the production; from the start till the end its main preoccupation remains the aftermath of violence. The allusions to the past are indirect, becoming visible only through displacement or indirect transposition, as in the setting itself, in which the background is a huge wooden wall that serves as 'a distant echo of the Jedwabne stable' (ROŻEK-SIERACZYŃSKA 2015). Warlikowski admits that his inter-generational memory of the Shoah is heavily textualised, and that it has been passed onto him through the writing of Hanna Krall, journalist and reporter who has devoted her life to documenting the Shoah, and with whom he started collaborating on his other theatrical projects, in which the themes of absent memory and the remembrance of the Shoah become more apparent (KRALL and WARLIKOWSKI 2009).

Even before its premiere, Warlikowski's production caused scandal owing to the refusal of Janus Gajos, the most revered actor of the older generation, to play Prospero, ostensibly as a result of the adaptation's investment in the historical discourse on Jedwabne. Despite the apparent lack of appreciation at the time, Warlikowski's contextualisation of the play within the larger schemata of inter-generational remembrance, responsibility, and forgiveness opens up a space for the investigation of The Tempest as an existential and political nightmare, in which World War II is evoked as a haunting intertextual trace:

Krzysztof Warlikowski is trying to set a zero point for the Polish discussion of the Shoah: the moment of transition from non-memory to memory, from non-consciousness to consciousness - and thereby strengthen his own artistic practice with the impetus of the repressed returning, as he would like to position his own theatre within such a zero point. (NIZIOŁEK 2013: 501)

\section{'Transmuted into myth':13}

\section{William Shakespeare's Tempest by Paweł Miśkiewicz}

Another production which seems to have made use of migratory aesthetics to evoke operations of postmemory was Burza Williama Szekspira [William Shakespeare's Tempest] directed by Paweł Miśkiewicz at the Polish National Theatre (Warsaw) in 2018. Considered the best 2018-2019 theatrical production in Poland (by the journal Theatre), it was described by Polish theatre critic Jacek Cieślak as '[a] non-obvious statement about the erosion of old authorities reminiscent of the best performances by Jerzy Grzegorzewski' (CIEŚLAK 2019). The name of Jerzy Grzegorzewski is used in the review

13 Marianne Hirsch quotes Eva Hoffman, who writes in After Such Knowledge about the way in which 'received transferred knowledge of the events is being transmuted into history, or into myth' (HIRSCH 2012: 1). 
very consciously, as this former director of the Polish National Theatre had staged his last production in 2003, the same year that Warlikowski produced his post-memorial opus magnum. Based on W. H. Auden's The Sea and the Mirror, Grzegorzewski's take on The Tempest was a major point of reference for Miśkiewicz's 2018 production. The sense of disrupted continuity between these two adaptations is strengthened by the fact that Jerzy Radziwiłowicz, who had played the role of Caliban alongside Grzegorzewski (Prospero) in 2003, was cast in 2018 in the role of the Duke of Milan, while the set design was created by Grzegorzewski's set designer of many years, Barbara Hanicka. Another intertext that figures prominently in Miśkiewicz's staging is the Swede Stig Dagerman's The Island of the Doomed (1946), a narrative of the last days of seven castaways whose individual memories encroach upon the present in a dream-like, thirst-induced frenzy, closely resembling Prospero's own fantasy. Through this haunting account of alienation on a desert island, Dagerman channels the trauma of the Nazi occupation and his existentialist angst:

the great flash of twilight that was hurled through the world singed away the little island where six human beings were being tortured together, by their hunger, their thirst, their sorrow, their paralysis. Nights came and went, days came and went, but hunger, thirst, sorrow and paralysis came back refreshed every morning; he saw hopes born, bitter furrows growing deeper, beards growing longer and more brutal, bodies becoming dirtier and smellier, [...] backs growing more rounded and submissive, eyes more defiant and crazed from lack of sleep and lack of hope, [...] feet growing more blood-stained and more careless about where they trod, words becoming fewer (DAGERMAN 2012 [1946]: 145).

Appearing in Polish translation on a gigantic screen in the background, this passage reads like a memento, the ominous presence of which is mediated through the digital text and lends an aura of imminent oblivion to the whole island. The burden of the historical past is never explicit, however, and remains obfuscated, safely hidden in the constellation of literary and theatrical quotes, borrowings, and inspirations which serve as a homage to Jerzy Grzegorzewski. ${ }^{14}$

Miśkiewicz's production proposes a hauntingly beautiful, but extremely fragmented reading of Prospero's island as a self-reflecting panopticon; Prospero's psychomachia becomes evident when the self-torturing deus ex machina peoples his desert with the phantasms of his unforgiveable past. In this production the sea and the mirror turn out to be one and the same. The setting initially consists of a simple black box design, an empty space with the closed curtain serving as the background. It soon transforms into the inside of a ship, and finally, once the curtain is up, it changes into a moon-lit seaside landscape. A closer look reveals that the audience is seated on the stage, facing the auditorium turned into the dark expanse of the ocean. It is the viewers that are stranded on the island, left together with Prospero to ponder the sins of omission and neglect. As Miśkiewicz claims:

14 'Melancholy and Auden make one think of Jerzy Grzegorzewski, the impressive scenes, of Jerzy Jarocki, and the poetic character, the symbolism [...] of Eimuntas Nekrošius. Ghosts, all of them' (KYZIOŁ 2018: 78). 
Auden showed me how to read this text through Prospero and the storm that had really unleashed in his mind long before. His head is filled with unresolved matters, figures from the past, a male adventure, Prospero's youth, understood as mobility and freedom from the corset he is now bound by. We are not really building a Shakespearean plot on the stage, but a certain spiritual landscape, which consists of Prospero's thought, sensitivity, and memory. $[\ldots]$ the viewer is given a share of constructing this performance so that it gains its final shape in his/her own mind. (MIŚKIEWICZ 2018)

Caliban and Ariel become one (Mariusz Benoit), and assume an adversarial position as Prospero's scapegoat, tormentor, and witness of his plight. These two, Prospero and Ariel-Caliban are locked in a dialogue based on The Sea and the Mirror which has every quality of a well-rehearsed scenario repeated ad nauseam (SIERADZKI 2019) in the confines of Prospero's mind-prison. Prospero's obsession with the past is underlined through recourse to contrasting methods of acting and through the use of intertextual tropes. Radziwiłowicz's grand technique contrasts with the lively performative delivery given by Benoit as well as with the performative phantasmagoria (or rather phantasmorgy) offered by graceful sailors who present a series of musical numbers, from sea shanties to acrobatic dances. These end in a Maori haka, a colonial appropriation serving to underline the fragile, constantly renegotiated masculinity of the island's prisoners. In the midst of the all-male alt 'bromance,' Miranda's (Maja Kleszcz) eerie operatic performance sounds like a phantasm created so that the haunted life in the desert is slightly more bearable. What is revealed towards its end is that Miranda is long gone, and that Prospero has been left to die alone.

Just as in Warlikowski's adaptation, in this production the catastrophe has already happened, and the plane has crashed amidst real drops of rain and wind that the spectators feel for themselves at the very beginning of the performance. Just like in that other case, some critics read Miśkiewicz's take of The Tempest through a political lens. The lived historical experience of the 2010 Smolensk catastrophe in which the Polish president Lech Kaczyński had died and which had catapulted his twin brother into power loomed heavily over the horizon of the critical expectations in which, to the horror of rightist and the exultation of leftist critics, 'political turbulences in Miśkiewicz's wreckage' (CIEŚLAK 2019) could be seen. For the leftist-leaning, Prospero is a leader touched by death, full of resentment and open rancour against his opponent, to whom he ascribes his own guilt for the past trespasses; for the conservatives, Prospero remains the enigma, while the pragmatically minded Antonio ushers forth 'associations with people from the current circles of power' (SZPAKOWSKI 2018). Miśkiewicz indeed references the lived reality as his intertext, but his concerns go beyond the local political context:

we are destroying our planet and each other; new utopias and ideas organising social life are compromised, therefore it is difficult to think optimistically. [...] What is more valuable than lulling one's vigilance and reassuring the belief that nothing is wrong with the world, is the awakening of the viewer from the lethargy of thoughtlessness and inertia. (MIŚKIEWICZ 2018) 
Miśkiewicz's adaptation has more to offer than the immediate politicised reading of Prospero's tired tour de force: it not only speaks of what there is in Poland to think about, to paraphrase Wyspiański. It also suggests what in the current political climate has become unthinkable and unspeakable. Prospero's despair and inability to meaningfully connect the past and the present are reflected in the overabundance of the intermedial and intertextual tropes, all of which paint a bleak portrait of mental ruin. These have a decisive effect on the overall tenor of the production, affecting the audience's reaction to the play and becoming a source of affective recognition for the viewers if only they manage to stay abreast of the deluge of the acknowledged sources: The Sea and the Mirror, Richard II, Richard III, Henry IV, Henry V, As You Like It, Shakespeare's Sonnet XXX, Blake's 'The Tyger', Nietzsche's On the Genealogy of Morals as well as Dagerman's The Island of the Doomed. Where Warlikowski's The Tempest serves as a displaced engagement with the unresolved traumas, Miśkiewicz's staging operates on the heavily mediated repression of trauma. Prospero does not want to admit the sins of omission that he is guilty of as a ruler; when faced by Antonio, he is unable to respond to his brother's accusations of guilt for the fatal neglect of his subjects and his daughter.

\section{'The future is but a repetition'15:}

\section{Recalling trauma in Shakespeare's 'no(w)here'}

In the $21^{\text {st }}$ century Polish theatre, The Tempest emerges as one of crucial Shakespearean narratives of unwanted memory and seems to serve as a pre-text for exploring the traumas of the past. Mobilising migratory aesthetics of displacement, Warlikowski's and Miśkiewicz's dystopian productions offer a reading of the Shakespearean drama that forces the spectator into an encounter with the fragmented narratives of loss and guilt which can mobilise the audience into a recollection of their own predicament. Warlikowski and Miśkiewicz engage that trauma indirectly, through strategies which in the psychoanalytical spirit of memory studies can be called dissociation and repression:

Discussions on whether repression or dissociation accompanies trauma can be brought to bear on the consideration of memory as narrative. In narratological terms, repression results in ellipsis - the omission of important elements in the narrative - whereas dissociation doubles the strand of the narrative series of events by splitting off a sideline. In contrast to ellipsis, this sideline is called paralipsis in narrative theory. In other words, repression interrupts the flow of narratives that shapes memory; dissociation splits off material that cannot then be reincorporated into the main narrative. (BAL 1999: ix)

Whereas Warlikowski strives to re-enact the trauma of the past, Miśkiewicz indexes it through an articulated absence. A larger issue that these two adaptations have in common is the question of the meaningfulness of action in the most meaningless 
of scenarios, that of a desert island read as a metaphor for the state of the past, the present, and the future. Despite its dystopian bitterness, however, these two stagings do offer a glimmer of hope. They open up the wounds of the past not to make them festered, but to potentially heal them through the felt experience of exclusion. By using fragmentary re-enactment scenarios of trauma which are mobilised and strengthened by diverse textual traces, these productions seem to reach out to viewers, fashioning them into witnesses of the violence and its aftermath. In the process they can potentially touch the deeply hidden strata of the collective cultural memory of the past as well as the unspoken, never-addressed collective traumas. Through the active choice of the audience, these ostensibly meaningless acts of dissociated re-enactment and intertextuality haunted by omission, can become 'acts of memory [...] an exchange between the first person and the second person that sets in motion the emergence of narrative' (BAL 1999: x). Within the dream-like paradigm of migratory aesthetics that 'remembrance warrants' (Tempest 1.2.46), The Tempest is in Poland not only to think about, but also to 'attend' (Tempest 1.2.77) to the untold, repressed, or dissociated postmemory of what still hurts.

\section{Bibliography}

BACCOLINI, Raffaella. 2013. Living in Dystopia. In Fátima Vieira (ed.). Dystopia(n) Matters: On the Page, on Screen, on Stage. Newcastle-upon-Tyne: Cambridge Scholars Publishing, 2013: 44-45.

BAL, Mieke. 1999. Introduction. In Mieke Bal, Jonathan Crewe and Leo Spitzer (eds.). Acts of Memory: Cultural Recall in the Present. Hanover and London: University Press of New England, 1999: vii-xvii.

BAL, Mieke. 2007. Lost in Space, Lost in the Library. In Sam Durrant and Catherine M. Lord (eds.). Essays in Migratory Aesthetics: Cultural Practices Between Migration and Art-Making. Amsterdam and New York: Rodopi, 2007: 23-36.

BRYŚ, Marta. 2020. Doświadczenie postpamięci w teatrze [Experience of Postmemory in Theatre]. Kraków: Wydawnictwo Uniwersytetu Jagiellońskiego, 2020.

BŽOCHOVÁ-WILD, Jana. 2003. Začarovaný ostrov? Shakespearova Búrka inak [The Enchanted Island? Shakespeare's The Tempest Otherwise]. Bratislava: Divadelný ústav, 2003.

CETERA, Anna. 2012. Wstęp [Introduction]. In William Shakespeare. Burza [The Tempest]. Transl. by Piotr Kamiński. Warszawa: W.A.B., 2012: 9-51.

CIEŚLAK, Jacek. 2019. Nie wciśniesz takiego do klatki [You Won't Cage One Such as Him]. [accessed on 27.08.2020]. Available online at http://www.teatr-pismo.pl/po-premierze/2247/ nie_wcisniesz_takiego_do_klatki/.

CZAPLIŃSKI, Lesław. 1990. 'Burza' czyli ostatnia pokusa utopii [The Tempest, Or the Last Temptation of Utopia]. Tygodnik Literacki 9 (18. 11. 1990). [accessed on 27.08.2020]. Available online at http://encyklopediateatru.pl/artykuly/263020/burza-czyli-ostatnia-pokusa-utopii. 
DAGERMAN, Stig. 1991. Island of the Doomed. Transl. by Laurie Thompson. Minneapolis: University of Minnesota Press, 1991.

DRÁBEK, Pavel. 2013. Shipwrecks on the Czech Sea: Tempest in Five Fits. Romanian Shakespeare Journal 1 (2013): 1: 25-36.

DROBNIK-ROGERS, Justyna. 2009. Krzysztof Warlikowski: Theatre as a Collective (Auto) Therapy. Theatre Forum 35 (2009): 10-16.

DUGGAN, Patrick. 2018. Trauma-Tragedy: Symptoms of Contemporary Performance. Manchester: Manchester University Press, 2018.

GALLARDO, Pere. 2013. Dystopia is You. In Fátima Vieira (ed.). Dystopia(n) Matters: On the Page, on Screen, on Stage. Newcastle-upon-Tyne: Cambridge Scholars Publishing, 2013: 37-39.

JETT, Renate. 2011. 'Teatr sam w sobie nie jest w stanie uzdrowić duszy narodu.' Z Renate Jett rozmawia Aneta Lukas ['Theatre Alone Cannot Heal the Soul of a Nation.' Renate Jett in Conversation with Aneta Lukas]. Interviewed by Aneta Lukas. LiteRacje (February 2011). [accessed on 27.08.2020]. Available online at http://pisane-do-szuflady.blogspot.com/2012/11/ teatr-sam-w-sobie-nie-jest-w-stanie.html.

FABISZAK, Jacek and Natalia BRZOZOWSKA. 2011. Magic Storms on Polish Television: The Case of The Tempest. Shakespeare Bulletin 29 (2011): 3: 359-369.

HEARD, Emma Marie et al. 2013. Shakespeare in Prison: Affecting Health and Wellbeing. International Journal of Prisoner Health 9 (2013): 3: 111-123.

HIRSCH, Marianne. 2012. The Generation of Postmemory: Writing and Visual Culture After the Holocaust. New York: Columbia University Press, 2012.

JONES, Phil. 1996. Drama as Therapy: Theatre as Living. London and New York: Routledge, 1996. KISTNER, Natalie. 2007. The Sources and Consequences of Public Perceptions of Corruption. In Kazimierz Słomczyński and Sandra Marquart-Pyatt (eds.). Continuity and Change in Social Life: Structural and Psychological Adjustment in Poland. Warsaw: IFiS Publishers, 2007.

KLAIĆ, Dragan. 1991. The Plot of the Future: Utopia and Dystopia in Modern Drama. Ann Arbor: University of Michigan Press, 1991.

KONIECZNA, Elżbieta. 1990. Burza [The Tempest]. Echo Krakowa 222 (15. 11. 1990). [accessed on 23.08.2020]. Available online at http://encyklopediateatru.pl/artykuly/263026/burza.

KOSIŃSKI, Dariusz. 2014. 'Idź i patrz'. Przemoc jako siła teatralna ['Go and Look.' Violence as Theatrical Force]. Ethos. Kwartalnik Instytutu Jana Pawta II KUL 27 (2014): 2: 353-364.

KOTT, Jan. 1991. Burza albo powtórzenie. [The Tempest, or Repetition]. In Tadeusz Nyczek (ed.). Jan Kott. Pisma Wybrane. Tom. II. Teatr Czytany [Jan Kott. Chosen Works. Vol. II. Theatre Read]. Warszawa: Wydawnictwo Krag, 1991: 159-199.

KOTT, Jan. 1990. Szekspir wspótczesny [Shakespeare, Our Contemporary]. Kraków: Wydawnictwo Literackie, 1990.

KRALL, Hanna and Krzysztof WARLIKOWSKI. 2009. Rzecz, która nie lubi być zabijana. Rozmowa z Hanną Krall i Krzysztofem Warlikowskim [The Thing that Doesn't Like Being Killed. Interview with Hanna Krall and Krzysztof Warlikowski]. Interviewed by Roman Pawłowski. Gazeta Wyborcza 2009 (18.05.2009) [accessed on 27.08.2020]. Available online at http://encyklopediateatru.pl/artykuly/72920/rzecz-ktora-nie-lubi-byc-zabijana. 
KUBIKOWSKI, Tomasz. 1991. Wizyta nie w porę [An Ill-timed Visit]. Teatr 2 (1. 02. 1991). [accessed on 23.08.2020]. Available online http://encyklopediateatru.pl/artykuly/263005/wizyta-nie-w-pore.

KYZIOŁ, Aneta. 2018. Taniec z duchami [Dancing with Ghosts]. Polityka 50 (12. 12. 2018): 78.

LANDY, Robert and David T. MONTGOMERY. 2012. Theatre for Change: Education, Social Action and Therapy. Basingstoke: Palgrave, 2012.

LANDY, Robert. 2011. Drama as a Means of Preventing Post-Traumatic Stress Following Trauma within a Community. Journal of Applied Arts $\mathcal{E}$ Health 1 (2010): 1: 7-18.

MIŚKIEWICZ, Paweł. 2020. Paweł Miśkiewicz: Taka 'Burza', jaki świat dokoła nas [Paweł Miśkiewicz: Such 'Tempests' As the World Around Us]. Interviewed by Lidia Raś. [accessed on 27.08.2020]. Available online at http://encyklopediateatru.pl/artykuly/268679/pawel-miskiewicz-taka-burza-jaki-swiat-dokola-nas.

NIZIOŁEK, Grzegorz. 2013. Polski Teatr Zagtady [The Polish Theatre of the Holocaust]. Warszawa: Instytut Teatralny im. Raszewskiego i Wydawnictwo Krytyki Politycznej, 2013.

NYCZEK, Tadeusz. Ocaleni z 'Burzy' [Saved from The Tempest]. Gazeta Wyborcza 16 (20. 01. 1992). [accessed on 23.08.2020]. Available online at_http://encyklopediateatru.pl/artykuly/263007/ ocaleni-z-burzy.

PAWŁOWSKI, Roman. 2003. Szekspir Warlikowskiego [Warlikowski’s Shakespeare]. Notatnik Teatralny 28-29 (2003): 180-189.

POŻAR, Przemysław. 2020. The Vacant Utopia: Reflecting on the First Polish Post-war Staging of The Tempest. Theatralia 23 (2020): 1: 131-149.

RATAJCZAKOWA, Dobrochna. 2005. In Transition: 1989-2004. Transl. by Paul Allain and Grzegorz Ziółkowski. Contemporary Theatre Review 15 (2005): 1: 17-27.

ROŻEK-SIERACZYŃSKA, Jadwiga. Czego nie widać.... [What You Can’t See...] Teatr 11 (28.11.2015). [accessed on 27.08.2020]. Available online at http://www.teatr-pismo.pl/ ludzie/1276/czego_nie_widac\%E2\%80\%A6/.

RUDA, Małgorzata. Burza w teatrze [The Tempest in Theatre]. Gazeta Krakowska 255 (2.11.1990). [accessed on 23.08.2020]. Available online at_http://encyklopediateatru.pl/artykuly/263024/ burza-w-teatrze.

SAKOWSKA, Aleksandra. 2011. No 'Happy Wrecks' - Pessimism and Suffering in Krzysztof Warlikowski's Adaptation of The Tempest by William Shakespeare. Shakespeare Bulletin 29 (2011): 3: 327-338.

SHAKESPEARE, William. 2016. The Tempest. In Stephen Greenblatt et al. (eds.). The Norton Shakespeare. New York and London: WW Norton, 2016: 3205-3266.

SIENKIEWICZ, Marian. Z czarów sztuką zrywam. [My Charms Are All O’erthrown]. Przekrój 2372 (9. 12. 1990). [accessed on 23.08.2020]. Available online at_http://encyklopediateatru. $\mathrm{pl} /$ artykuly/263014/z-czarow-sztuka-zrywam.

SIERADZKI, Jacek. 2019. Subiektywny spis aktorów teatralnych. Edycja dwudziesta siódma Mariusz Benoit [mistrzostwo] [Subjective List of Theatre Actors. Twenty-Seventh Edition. Mariusz Benoit, exquisite]. [accessed on 27.08.2020]. Available online at http://encyklopediateatru.pl/ artykuly/279261/subiektywny-spis-aktorow-teatralnych 4 września 2019.

SILVERSTONE, Catherine. 2012. Shakespeare, Trauma and Contemporary Performance. New York and London: Routledge, 2012. 
SZPAKOWSKI, Jacek. Zagadka Prospera [Prospero's Secret]. Gazeta Polska Codziennie 282 (4. 12. 2018). [accessed on 27.08.2020]. Available online at_http://encyklopediateatru.pl/artykuly/268086/zagadka-prospera.

ŚMIECHOWICZ, Olga. 2018. Polish Theatre After the Fall of Communism: Dionysus Since '89. Newcastle-upon-Tyne: Cambridge Scholars Publishing, 2018.

VIEIRA, Fátima. 2013. Introduction. In Fátima Vieira (ed.). Dystopia(n) Matters: On the Page, on Screen, on Stage. Newcastle-upon-Tyne: Cambridge Scholars Publishing, 2013: 1-7.

WARLIKOWSKI, Krzysztof. 2003. 'Burza we mnie.' Rozmowa z Krzysztofem Warlikowskim, twórca głośnych inscenizacji teatralnych ['The Tempest Inside Me.' Interview with Krzysztof Warlikowski, the Maker of Famous Theatrical Productions]. Interviewed by Roman Pawłowski. Gazeta wyborcza (6. 03. 2003). [accessed on 27.08.2020]. Available online at https://wyborcza. $\mathrm{pl} / 1,75410,1357475 . \mathrm{html}$.

WARLIKOWSKI, Krzysztof. 2012. Wykluczony, czyli każdy. Z Krzysztofem Warlikowskim rozmawia Katarzyna Fazan [Excluded: Each One of Us. Katarzyna Fazan Speaks with Krzysztof Warlikowski]. Interviewed by Katarzyna Fazan. Didaskalia 107 (2012): 8-14. 


\section{Anna Kowalcze-Pawlik}

International Shakespeare Centre

Faculty of International and Political Studies

University of Łódź

Składowa 43, 90-127 Łódź, Poland

anna.kowalcze@uni.lodz.pl

ORCID: https://orcid.org/0000-0002-7606-7127

Anna Kowalcze-Pawlik is an assistant professor at the Department of the British and Commonwealth Studies at the Faculty of International and Political Studies, University of Łódź, where she teaches literary and cultural studies and serves as the assistant editor of International Studies: Interdisciplinary Political and Cultural Journal. She is also affiliated with the International Shakespeare Centre, University of Łódź. Anna Kowalcze-Pawlik is a board member of the Polish Shakespeare Society, where she has been serving as the vice president since 2018. Her main fields of research are cultural history of emotions, literary theory and translation, and Shakespeare in performance. Winner of the START Polish Science Foundation scholarship for young scholars, the Polish Minister of Science and Higher Education scholarship for outstanding doctoral students, and the Ministerial scholarship for outstanding young scholars (2017-2019), she was a principal investigator in Polish National Science Centre PRELUDIUM (2012-2014) and ETIUDA (2013-2015) grants, as well as Polish National Centre for Research and Development project Between Literature and Philosophy: Conflict and Dialogue (2017-2018). She is working on a book on women's revenge in early modern English drama and a project on the reception of The Tempest in Poland. 